Commentary

\title{
Climate Crisis and Communication: Reflections on Naomi Klein's This Changes Everything
}

\author{
Robert A. Hackett \\ School of Communication, Simon Fraser University, Burnaby, BC V5A 1S6, Canada; E-Mail: hackett@sfu.ca
}

Submitted: 27 April 2015 | Accepted: 6 May 2015 | Published: 1 June 2015

\begin{abstract}
This commentary suggests that Naomi Klein's influential book This changes everything: Capitalism vs. the climate, implicitly points to the influence of media institutions on societal response to the crisis, yet does not analyze them explicitly. Communication scholars could help fill that gap. Conversely however, Klein's work suggests productive avenues for media researchers to explore, including a fresh take on the relationship between climate crisis, communication and capitalism as a system, and the potential for alternative media to challenge dominant cultural narratives.
\end{abstract}

\section{Keywords}

alternative media; capitalism; climate crisis and media; journalism; media reform

\section{Issue}

This commentary is part of a regular issue of Media and Communication, edited by Professor Bradley Greenberg (Michigan State University, USA) and Professor Elisabeth Klaus (University of Salzburg, Austria).

(C) 2015 by the author; licensee Cogitatio (Lisbon, Portugal). This article is licensed under a Creative Commons Attribution 4.0 International License (CC BY).

\section{Introduction}

The surging tide of climate crisis is sweeping media studies towards new ethical and intellectual imperatives. Most obviously, it forces us to consider how to reduce our own carbon footprint. Even if academic tourism makes only a tiny contribution to greenhouse gas emissions, and granted the undoubted value of face-to-face meetings, we could demonstrate ethical leadership by modelling new modes of collaboration, including greener and less frequent conferences, and payment of carbon offsets-not the corporatesponsored greenwashing programs, but personal engagement and donations to civil society organizations campaigning for effective climate policy.

Climate crisis urges communication scholars to reflect upon their own conceptual tools and research agendas. Climate crisis can be incorporated into longstanding concerns in critical media studies with power, inequality, representation and ideology. Critical social science in general has introduced new concepts, such as "productivism" as a form of oppression parallel to and overlapping with racism, sexism, and capitalism.

\section{Klein's Themes}

Given expanding attention to climate crisis in a range of disciplines, Naomi Klein's book This changes everything: Capitalism vs. the climate (2014) deserves more consideration than it has received so far from critical communication scholars. Encyclopedic in scope, and based on several years of team-based research, This changes everything: Capitalism vs. the climate resists easy summary, but relevant themes include these: as an ontological threat to civilization, global climate change forces a rethinking and retooling of human institutions and practices. Neither geoengineering technology, benevolent billionaires, nor market forces, are probable saviours. To the contrary-free market fundamentalism and capitalist globalization have helped create the crisis, partly through free trade agreements that trump and undermine governments' willingness and ability to enact proclimate policies. Indeed, Klein traces the crisis's origins to the coal-fuelled emergence of industrial capitalism in Britain, inextricably intertwined with colonialism, slavery and racism. Thus, attitudes to climate change are a barometer of other political values; the Right is correct that 
taking it seriously requires a positive role for government, a strengthened public sector, and collective action-which is precisely why the Right prefers not to take climate change seriously! The dominant cultural narratives of perpetual growth and human domination of nature are also part of the problem, as is the complicity of many mainstream environmental groups with neoliberalism and the fossil fuel industry.

But there are sources of hope and renewal. Fossilfuelled capitalism has always generated "sacrifice zones" and exploitable or expendable people, comprising a kind of global apartheid stratified along class, gender and geographic as well as racial lines. But as extreme energy extraction encroaches upon previously privileged enclaves in the global North, new alliances, resistances, and political possibilities emerge, including growing support for the determination of indigenous people to defend their lands. Other positive assets include the rapidly developing technological feasibility of renewable energy; a repertoire of workable policies, some already modelled, to rein in climate change and to pay the global North's climate debt to the South; and the reclaimed memory of past social movements (notably slavery abolitionists) that overcame overwhelming odds.

\section{Media as an Underdeveloped Theme?}

What about media and communication? Periodically, Klein notes omissions in corporate media reportage, such as grassroots victories against fossil fuel industries, or the impact of oil spills on the life-cycle of plants and animals. More important, media-from Hollywood blockbusters and reality TV to the daily press-collude with other ideologies and interests in shaping dominant narratives - the veneration of profit, denigration of collective action, a politically debilitating belief that humanity is selfish and greedy (p. 461), and depictions of a dystopic future with a few big corporate winners and many locked-out losers ( $p$. 59). While the analysis throughout emphasizes the political significance of cultural narratives, however, the institutions that circulate them remain largely unexamined.

Critical communication scholars could help write that arguably "missing" chapter, focussing on the imbrication of communication policies, practices and structures with climate change and sustainability. There is already an extensive literature on journalism and climate change, particularly environmental deficits of news coverage-the unwarranted attention to climate deniers in earlier days, episodic rather than sustained attention, little focus on solutions, a narrow focus on official politics, an overriding disconnect "between the media's representations of climate change and the politics and policies needed to effect meaningful change" (Cottle, 2009).

Beyond journalism coverage, an emerging critical theme is the environmental damage from information and communication technology industries themselves. Largely under the radar screen by contrast with compara- ble emissions from transport industries, these include built-in obsolescence of digital gadgets, and the dumping of toxic materials in the global South, driven by the marketing and surveillance needs of business - but also by technofetishism in popular culture (Maxwell \& Miller, 2012).

Adjacent to media studies, students of popular and political culture could explore the cultural implications of the increasingly brutal scramble for diminishing energy resources, the unevenly distributed consequences of global warming, the refusal of capital rooted in the global North to pay its climate debt. Given the tendency of cultural studies to privilege epistemology over ontology, there is a risk of overemphasizing the "discursive" construction of crisis, at the expense of exploring cultural implications of the very material processes of ecological degradation. Still, there is a need for more research on how the framing of energy politics and environmental crisis, in journalism, media and other cultural forms, influence the potential for popular political action. Moreover, parallel to political scientists researching global warming's impact on political instability, cultural researchers could consider whether climate crisis is contributing to the apparent decline of universalism, the retreat to "tribal" identities, an upsurge in nihilistic and fascistic movements, from ISIS to European and American antiimmigrant xenophobia-but also the emergence of new forms of transnational resistance and solidarity.

\section{Potential Contribution to Communication Studies}

While critical communication scholarship could expand Klein's book, her work conversely suggests themes that could enrich the communication field. Klein's identification of capitalism as an object of analysis in connection with climate catastrophe provides a new lens for considering the capitalism-communication nexus. To be sure, controversy surrounds the target of Klein's critique: is it capitalism as such, or particular manifestations of it? Liberal commentators have undertaken a recuperative operation, interpreting her as a critic of neoliberalism rather than a full-blooded anti-capitalist, which in their view would put her beyond the pale of legitimate debate (Foster, 2015). Her book can be read either way. Her analysis of the connection between coal, industrialism, colonialism, slavery and racism, suggests a systemlevel critique. Elsewhere in the book, however, the "enemy" receives more qualifiers-unfettered, contemporary, hyper-globalized, or deregulated capitalism, or market fundamentalism, or the growth ethic, or "the rules of capitalism as they are currently constructed" (p. 88)-as distinct from capitalism per se.

Fair enough. Hers is a work of intensely researched journalism, not of social theory as such. Arguably, the ambiguity is productive. It opens the tent to progressives of various hues, while still naming and foregrounding capitalism-not simply industrial pollution, fossil fuels, or consumerism-as a system requiring analysis and 
fundamental change.

Interestingly, a similar trend is observable in the critical political economy of media. Of course, ownership, control, revenues and the subordination of media organizations to corporate imperatives, are longstanding themes in the political economy research. Implications include loss of diversity as editorial resources are rationalized within corporate empires; disinvestment in serious journalism as media are increasingly owned by conglomerates seeking short-term profits; the inability of volunteer-driven online journalism to fill the gap; and the eroding separation between marketing and news (McChesney \& Nichols, 2010). As a leading media reform advocate and journalism scholar, McChesney (2013, 2014) has expanded his critique to the governing logics of capitalism, as a force that constrains the democratic potential of the Internet, the press, and indeed, the space for media reform through the state. Even further, Almiron (2010) sees a qualitative leap in the integration of news media with contemporary capitalism; as finance capital comes to dominate the industrial sphere, corporate media prioritize financial information and services at the expense of journalism, and become speculative actors themselves, desperate to increase profits and revenues (Boyd-Barrett, 2011).

A new prism is thus suggested for research: the triangular relationship between capitalism, communication and climate crisis. Most obviously, capital logic fuels hegemonic media's need to attract profitable upscale audiences, media's imbrication with the growth of the urban middle class in global capitalism's "emerging economies" like India and China, and media's sustained effort to colonize popular imagination with consumerist lifestyles. Journalism suborned by such imperatives will inevitably be muted on an issue that implicitly evokes the need for collective action beyond market constraints, consumerism and property rights. Advertising helps to create "a set of cultural conditions that makes us less inclined to deal with climate change", so that "a media and telecommunications industry fuelled by advertising and profit maximisation is, at the moment, part of the problem rather than part of the solution" (Boyce \& Lewis, 2009, pp. 8-9). And yet...significant portions of audiences care about environmental issues, and occasionally the process of global warming erupts with newsworthy impact. Researchers could further explore how hegemonic media handle this potential contradiction.

Klein's critique, however, doesn't simply return us to the "radical functionalism" (Curran, 2002, pp. 137-139) of 1970s western Marxist views of media and state as irredeemably locked into the reproduction of capitalism. Nor does it nestle in the fuzzy terrain of green lifestyles or deracinated consensus-building. Her sharpest critiques target "extreme energy extraction" and the fossil fuel industries as in effect an enemy of humanity-a perspective shared with American environmental writer Bill McKibben and his 350.org, on whose board Klein serves. Her book explores the irruption of "Blockadia", community-based popular resistance to extreme energy around the world. Her incendiary call for militant agency presages the possibilities of radical transformation, and resonates richly with existing research and activism. It gives an additional motive, beyond redressing the injustices of colonialism, for supportive engagement with indigenous cultures and rights, since "...Indigenous rights-if aggressively backed by court challenges, direct action, and mass movements demanding that they be respected-may now represent the most powerful barriers protecting all of us from a future of climate chaos" (p. 380). Klein's work suggests an agenda of exploring and exposing the tentacles of the fossil fuel industries in particular, into the political, cultural and media fields. Previous research on the social determinants of news agendas suggests the potential mechanisms of power, including interlocking corporate boards, revenue flows, industry-funded think tanks, political campaign donations, sponsorship of plush journalism seminars and editorial segments, well-oiled legal teams, the regime of objectivity and other aspects of conventional journalism culture, and much else (e.g. Hackett \& Zhao, 1998; Shoemaker \& Reese, 1996).

\section{Changing the Media Field Too}

Yet Klein's implicit evocation of the media's role in shaping political imagination and cultural narratives, and her explicit celebration of hope and resistance, also suggest the importance and potential for transformation in the media field. The media field is structured in dominance, but not without contradictions, even in the era of neoliberal financialization. What are the prospects within hegemonic news organizations for better practices and frames, more conducive to forming, engaging and mobilizing resistant publics? The crusading climate journalism of the not-for-profit Guardian, with its international online readership, offers one inspiring model, albeit one that requires cross-subsidization from related corporations. What about emergent paradigms, whole new ways of reporting the world? Does "civic" (or "public") journalism, a movement that flourished in the US in the 1990s, or peace journalism, attracting interest in conflict-ridden societies of the global South, offer valuable techniques and experience for more effective climate journalism?

Probably they do, but the exigencies of marketdriven media, the 24-hour news cycle, conventional news values and practices, and the structural ties to financial capital, are hardly conducive to climate journalism that both requires extended research and challenges the culture of consumerism. While there are some excellent blogs and websites, the growing army of precariously employed freelance journalists, scrambling for scraps from the table of media empires, cannot be expected to fill the gap. Both the content of Klein's book, and its form as itself a species of long-form journalism-one that entailed several years of collaborative research, 
twinned with a forthcoming video documentary produced by her partner Avi Lewis-, indicate the importance of genres of reality-oriented narrative beyond the daily headlines of hegemonic media.

At least two paths are open. Structural reform of the political communication system, particularly to ensure the financing of public interest journalism that is independent of capital logic, and especially the extractive energy sector, is one (McChesney \& Nichols, 2010). The other is to strengthen "alternative" media already operating alongside, outside and sometimes against hegemonic media, typically in the online environment (whose own class, gender and geo-cultural biases, however, should not be ignored). Alternative media have traditions that resonate with progressive and just climate politics. Some of these characteristics are vulnerable to co-optation; participatory production processes, for example, can be exploited as "user generated content" for hegemonic media. Other aspects with hardier oppositional potential include productive relationships with local communities and/or social movements; a positive orientation to social change, advocacy journalism, and popular political engagement; and counter-hegemonic or "critical" content (Atton \& Hamilton, 2008; Downing, Ford, Gil, \& Stein, 2001; Fuchs, 2010).

\section{Conclusion}

Naomi Klein has outlined an ontological crisis that requires progressive communication scholars and journalists to take sides, between extractive capitalism and societal well-being. If successful challenges to extractive capitalism require deeper democracy, as Klein argues, there is an overlapping agenda between democratic media reformers, alternative media, and the emerging global climate justice movement.

\section{Acknowledgements}

My thanks to Prof. Shane Gunster, Communication, Simon Fraser University, and this journal's editors, for comments on a draft of this article.

\section{Conflict of Interests}

The author declares no conflict of interest.

\section{References}

Almiron, N. (2010). Journalism in Crisis: Corporate media and financialization. Cresskill, NJ: Hampton Press.

Atton, C., \& Hamilton, J. F. (2008). Alternative journalism. London: Sage.

Boyce, T., \& Lewis, J. (2009). Climate change and the media: The scale of the challenge. In T. Boyce \& J. Lewis (Eds.), Climate change and the media (pp. 316). New York: Peter Lang.

Boyd-Barrett, O. (2011). Review of N. Almiron, Journalism in crisis. Journalism \& Mass Communication Quarterly, 8(2), 449-450.

Cottle, S. (2009). Senior editor's preface: Global crises and the media. In T. Boyce \& J. Lewis (Eds.), Climate change and the media (pp. vii-xi). New York: Peter Lang.

Curran, J. (2002). Media and power. London and New York: Routledge.

Downing, J. D. H., Ford, T. M., Gil, G., \& Stein, L. (2001). Radical media: Rebellious communication and social movements. Thousand Oaks: Sage.

Foster, J. B. (2015). Crossing the river of fire: The liberal attack on Naomi Klein \& This Changes Everything. Monthly Review, 66(9), 1-17.

Fuchs, C. (2010). Alternative media as critical media. European Journal of Social Theory, 13(2), 173-192.

Hackett, R., \& Zhao, Y. (1998). Sustaining democracy? Journalism and the politics of objectivity. Toronto: Garamond.

Klein, N. (2014). This changes everything: Capitalism vs. the climate. Toronto: Knopf Canada.

Maxwell, R., \& Miller, T. (2012). Greening the media. New York: Oxford University Press.

McChesney, R. W. (2013). Digital disconnect: How capitalism is turning the internet against democracy. New York: New Press.

McChesney, R. W. (2014). Sharp left turn for media reform. Monthly Review, 65(9), 1-14.

McChesney, R. W., \& Nichols, J. (2010). The death and life of American journalism: The media revolution that will begin the world again. Philadelphia: Nation Books.

Shoemaker, P., \& Reese, S. (1996). Mediating the message: Theories of influences on mass media content (2nd ed.). White Plains, NY: Longman.

\section{About the Author}

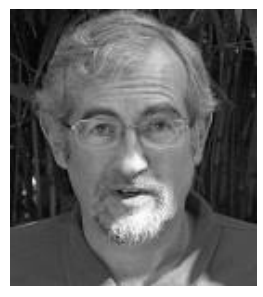

Dr. Robert Hackett

Robert A. Hackett is a Professor of Communication at Simon Fraser University, Vancouver. He has recently researched in the areas of media reform, journalism studies, and climate change and the media. His collaborative publications include Remaking media: The struggle to democratize public communication (2006) and Expanding peace journalism: Comparative and critical approaches (2011). He has co-founded several community-oriented media monitoring and media reform initiatives, including openmedia.ca and Media Democracy Days. 